\title{
Karakteristik Ibu Hamil dengan HIV/AIDS di RSUP Dr. Hasan Sadikin Bandung Periode 2014-2016
}

\author{
Romy Ade Putra, Hadi Susiarno, Anita Rachmawati, Windi Nurdiawan \\ Departemen Obstetri dan Ginekologi Fakultas Kedokteran Universitas Padjadjaran \\ Rumah Sakit Dr. Hasan Sadikin Bandung \\ Korespondensi: Romy Ade Putra, Email: romyadeputra@gmail.com
}

\begin{abstract}
Abstrak
Tujuan: Untuk mengetahui karakter HIV/AIDS selama kehamilan di Rumah Sakit Dr. Hasan Sadikin Bandung sejak Januari 2014 sampai Desember 2016.

Metode: Studi retrospektif terhadap HIV/AIDS selama kehamilan di Klinik Rawat Jalan Teratai di Rumah Sakit Dr. Hasan Sadikin Bandung, dengan mengumpulkan data dari rekam medis pasien baru mulai bulan Januari 2014 sampai Desember 2016. Ciri khasnya adalah usia, pekerjaan, tingkat pendidikan, cara transmisi, tempat tinggal, status perkawinan dan sejarah pengobatan anti retroviral.

Hasil: Terdapat 102 kasus wanita hamil dengan HIV/AIDS sejak Januari 2014 sampai Desember 2016. Sebagian besar kasus ditemukan pada usia 30-39 tahun, 63 kasus (61,8\%). 69 (67,6\%) pasien adalah ibu rumah tangga. Sebanyak $55(53,9 \%)$ pasien telah menyelesaikan sekolah menengah atas. Sebagian besar kasus adalah transmisi heteroseksual $95(93,13 \%)$ dan $96(94,1 \%)$ pasien sudah menikah.

Kesimpulan: Terdapat perubahan karakteristik wanita hamil dengan infeksi HIV / AIDS di Rumah Sakit Dr.Hasan Sadikin Bandung.
\end{abstract}

Kata kunci: HIV/AIDS, kehamilan

\section{The Characteristics of Pregnant Women with HIV/AIDS Infection in Dr. Hasan Sadikin General Hospital Bandung in 2014-2016}

\begin{abstract}
Objective: To find the characterics of HIVIAIDS during pregnancy in Dr. Hasan Sadikin Hospital Bandung since January 2014 to December 2016.

Method: Retrospective study of HIV/AIDS during pregnancy in Teratai Outpatient Clinic of Dr.HasanSadikin Hospital Bandung, by collecting data from the medical record of new patients from January 2014 to December 2016. The characteristics are age, occupation, education level, mode of transmission, residence, marital status and history of anti retroviral treatment.

Result: there are 102 cases of pregnant women with HIV/AIDS since January 2014 to December 2016. The most cases are found in 30-39 years old, 63 cases (61.8\%). 69 (67.6\%) patients are housewife. 55 (53.9\%) patients had completed senior high school. The most cases are heterosexual transmission 95 (93.13\%). 96 (94.1\%) patients are married.

Conclusion: There are changes in characteristics of pregnant women with HIV infection /AIDS in Dr.Hasan Sadikin Hospital Bandung.
\end{abstract}

Key words: $H I V / A I D S$, pregnancy 


\section{Pendahuluan}

Human Immunodeficiency Virus (HIV) ialah Virus RNA yang termasuk virus famili retrovirus yang menyerang komponen sistem imun manusia, yakni sel limfosit T-Cluster of Differentiation 4 (CD 4), makrofag, dan sel langerhans. Infeksi dari virus ini akan menyebabkan kadar sel CD4 semakin lama semakin menurun melalui mekanisme tertentu. Pada saat kadar CD4 kurang dari $200 \mathrm{sel} / \mathrm{mm}^{3}$, terjadilah kegagalan fungsi dari sistem imun membuat tubuh lebih mudah terserang infeksi oportunistik dan keganasan. Keadaan inilah yang disebut dengan Acquired Immune Defficiency Syndrome (AIDS). ${ }^{1}$ Berdasarkan United Nations Program on HIV/AIDS dan World Health Organization tahun 2014 diperkirakan terdapat 36,7 juta orang yang terinfeksi HIV AIDS dan 2,1 juta dengan kasus baru infeksi HIV.2 Jumlah kasus HIV di Indonesia cenderung meningkat setiap tahunnya. Jumlah kumulatif penderita HIV pada tahun 2014 adalah 150.296 orang dengan jumlah kasus AIDS 55.799 orang. ${ }^{3}$ Kementerian Kesehatan memperkirakan pada tahun 2016 Indonesia akan mempunyai hampir dua kali jumlah orang yang hidup dengan HIV dan AIDS dewasa dan anak (812.798 orang) dibandingkan pada tahun 2008 (411.543 orang), bila upaya penanggulangan HIV dan AIDS yang dilaksanakan tidak adekuat sampai kurun waktu tersebut. ${ }^{4}$

Jawa barat menempati peringkat keempat dari seluruh provinsi di Indonesia setelah DKI Jakarta, Jawa Timur dan Papua. Estimasi orang dengan positif HIV/AIDS di Jawa Barat sekitar 23.416 orang dengan yang terlapor hingga bulan Maret 2012 hanya sekitar 4043 orang. Berdasarkan jenis kelamin, menurut data Maret 2011, dari 3.537 kasus AIDS yang dilaporkan, sebanyak 2.731 adalah laki-laki, 798 perempuan dan 8 orang tidak diketahui jenis kelaminnya. Sementara cara penularan HIV terbanyak di Jawa Barat adalah dari pengguna narkotika dan zat adiktif suntik (Penasun) dengan persentase 70,03 \% dan heterosex $21,09 \%$. Cara penularan HIV ini cenderung berubah. Pada tahun 2013 dari pasien yang berobat ke Klinik Teratai Rumah Sakit Hasan Sadikin (RSHS) ternyata paling banyak pasien tertular HIV karena hubungan sex antara lawan jenis (heterosex). Di Jawa Barat, Bandung menjadi kota terbanyak kasus AIDS dengan angka kematian yang tinggi. Dari 1.424 kasus AIDS, 157 orang dilaporkan meninggal. ${ }^{5}$

Untuk menurunkan angka kejadian HIV/AIDS diperlukan pusat-pusat pelayanan pengobatan dan pencegahan HIV/AIDS. Menurut data dari Pusat Komunikasi Publik (Puskom Publik) Kementerian Kesehatan Republik Indonesia, sampai dengan september 2012 sudah tersedia layanan HIV/ AIDS di Indonesia sebanyak 460 layanan konseling dan tes HIV yang diprakarsai oleh petugas kesehatan. Di Jawa Barat, khususnya di Rumah Sakit Hasan Sadikin (RSHS), terdapat Klinik Teratai sebagai pusat layanan HIV/AIDS. Program yang dilakukan Klinik Teratai untuk menurunkan angka penularan HIV/AIDS, khususnya pada perempuan, adalah dengan program 4 prong, yaitu pencegahan utama HIV di kalangan perempuan usia reproduksi, pencegahan kehamilan pada ibu dengan HIV positif, pencegahan penularan HIV dari ibu ke anak pada ibu hamil dengan HIV positif, dan program dukungan medis dan psikososial terhadap ibu dan anak dengan HIV positif. ${ }^{5,6}$ Meskipun data prevalensi dan penularan HIV dari ibu ke bayi masih terbatas, jumlah ibu hamil yang terinfeksi HIV cenderung meningkat. Lebih dari $90 \%$ kasus anak terinfeksi HIV melalui proses penularan dari ibu ke anak atau mother to child HIV transmission (MTCT). ${ }^{4,7}$ Human Immunodeficiency Virus dapat ditularkan dari ibu yang terinfeksi HIV kepada anaknya selama kehamilan, saat persalinan dan saat menyusui. Data Kementerian Kesehatan 
(2011) menunjukkan dari 21.103 ibu hamil yang menjalani tes HIV, 534 (2,5\%) di antaranya positif terinfeksi HIV. Prevalensi HIV pada ibu hamil diproyeksikan meningkat dari 0,38\% (2012) menjadi 0,49\% (2016). ${ }^{4}$ Risiko penularan $15-30 \%$ terjadi pada saat hamil dan bersalin, sedangkan peningkatan risiko transmisi HIV sebesar $10-20 \%$ dapat terjadi pada masa nifas dan menyusui. ${ }^{8}$

Untuk mencegah dan menurunkan angka penularan HIV terutama pada ibu hamil, perlu diketahui karakteristik ibu hamil dengan infeksi HIV. Karakteristik tersebut adalah usia, pekerjaan, tingkat pendidikan, cara penularan, tempat tinggal, status pernikahan dan riwayat pengobatan anti retroviral. Dari data situasi dan analisis HIV/AIDS terlihat perubahan karakteristik penderita HIV pada periode waktu tertentu, seperti perubahan kelompok usia terbanyak yang terinfeksi HIV dan cara penularannya. Untuk itu perlu dilakukan penelitian untuk mengetahui karakteristik ibu hamil dengan infeksi HIV saat ini agar program pencegahan, pengobatan dan konseling sebagai usaha untuk menekan angka penularan HIV pada ibu hamil lebih efektif.

Bagaimana karakteristik ibu hamil dengan infeksi HIV di Rumah Sakit dr. Hasan Sadikin periode tahun 2014-2016?

Untuk mengetahui karakteristik ibu hamil dengan infeksi HIV di Rumah Sakit dr. Hasan Sadikin periode tahun 2014-2016.

1. Data yang diperoleh dari penelitian ini diharapkan dapat digunakan sebagai data dasar penelitian lebih lanjut mengenai ibu hamil dengan infeksi HIV.

2. Data dasar untuk melakukan evaluasi mengenai karakteristik ibu hamil dengan HIV, sehingga dapat digunakan sebagai pertimbangan untuk mengoptimalkan pelayanan kesehatan terhadap ibu hamil dengan infeksi HIV.

\section{Metode}

Penelitian ini merupakan suatu penelitian deskriptif retrospektif. Penelitian dilakukan di Klinik Teratai RS dr. Hasan Sadikin Bandung mulai bulan Maret-Mei 2017. Sampel penelitian adalah semua kasus ibu hamil dengan HIV yang datang ke Klinik Teratai RS dr. Hasan Sadikin Bandung dalam periode 1 Januari 2014-31 Desember 2016. Data untuk penelitian ini didapatkan dari buku register pasien Klinik Teratai RS dr. Hasan Sadikin Bandung dalam periode 1 Januari 2014-31 Desember 2016 dan rekam medis pasien hamil dengan HIV dalam periode 1 Januari 2014-31 Desember 2016. Data yang diperoleh kemudian disusun dan ditabulasi serta disajikan dalam bentuk tabel dan naratif.

\section{Hasil}

Dari data yang diperoleh dari buku register pasien Klinik Teratai Rumah Sakit Hasan Sadikin Bandung dalam periode 1 Januari 2014-31 Desember 2016 didapatkan 102 kasus ibu hamil dengan infeksi HIV/ AIDS. Karakteristik ibu hamil dengan infeksi HIV yang dinilai adalah usia, paritas, faktor resiko, pekerjaan, pendidikan dan status pernikahan. Karakteristik tersebut dapat dilihat pada tabel-tabel berikut:

Pada tabel 1 terlihat bahwa usia terbanyak ibu hamil dengan infeksi HIV/ AIDS pada penelitian ini yaitu rentang usia 30-39 tahun (60,8\%) diikuti usia 20-29 tahun $(29,4 \%)$, usia lebih dari 40 tahun $(9,8 \%)$, dan tidak ditemukan pada usia dibawah 20 tahun.

Tabel 1. Usia ibu hamil dengan infeksi HIV/AIDS di Rumah Sakit Hasan Sadikin Bandung periode 1 Januari 2014-31 Desember 2016. 
Tabel 1 Usia Ibu Hamil dengan Infeksi HIV/AIDS di RSUP Dr. Hasan Sadikin Bandung Periode 1 Januari 2014-31 Desember 2016

\begin{tabular}{ccc}
\hline Usia (Tahun) & Jumlah & Persentase (\%) \\
\hline$<20$ & 0 & 0 \\
$20-29$ & 30 & 29,4 \\
$30-39$ & 62 & 60,7 \\
$>40$ & 10 & 9,8 \\
\hline
\end{tabular}

Pada tabel 2 memperlihatkan jumlah paritas lebih dari 1 merupakan jumlah yang terbanyak ditemukan yaitu $(89,2 \%)$ dan tidak ditemukan pada pasien dengan paritas 0 .

Tabel 2 Paritas Ibu Hamil dengan Infeksi HIV/AIDS di RSUP Dr. Hasan Sadikin Bandung Periode 1 Januari 2014-31 Desember 2016

\begin{tabular}{ccc}
\hline Paritas & Jumlah & Persentase (\%) \\
\hline 0 & 0 & 0 \\
1 & 11 & 10,8 \\
$>1$ & 91 & 89,2 \\
\hline
\end{tabular}

Tabel 3 Faktor Risiko Ibu Hamil dengan Infeksi HIV/AIDS di RSUP Dr. Hasan Sadikin Bandung periode 1 Januari 2014-31 Desember 2016

\begin{tabular}{lcc}
\hline \multicolumn{1}{c}{ Faktor risiko } & Jumlah & Persentase (\%) \\
\hline Heteroseksual & 93 & 91,2 \\
Narkoba suntik & 8 & 7,9 \\
Homoseksual & 1 & 0,9 \\
Lain-lain & 0 & 0 \\
\hline
\end{tabular}

Faktor risiko heteroseksual merupakan faktor resiko tertinggi infeksi HIV/ AIDS ibu hamil pada penelitian ini, yaitu sebanyak 91,2\%, diikuti narkoba suntik 7,9\%, homoseksual $0,9 \%$ dan lain-lain. Tabel 4. Pekerjaan ibu hamil dengan infeksi HIV/ AIDS yang terbanyak pada penelitian ini adalah ibu rumah tangga (66,7\%). Angka ini jauh lebih tinggi dari jenis pekerjaan lainnya. Jenis pekerjaan kedua terbanyak adalah pegawai swasta, yaitu sebanyak $12,8 \%$, kemudian diikuti jenis pekerjaan lain dengan persentase yang lebih rendah.
Tabel 4 Pekerjaan Ibu Hamil dengan infeksi HIV/AIDS di RSUP Dr. Hasan Sadikin Bandung Periode 1 Januari 2014-31 Desember 2016

\begin{tabular}{lcc}
\hline \multicolumn{1}{c}{ Pekerjaan } & Jumlah & $\begin{array}{c}\text { Persentase } \\
(\mathbf{\%})\end{array}$ \\
\hline Ibu rumah tangga & 68 & 66,7 \\
Swasta & 13 & 12,8 \\
Wiraswasta & 10 & 9,8 \\
PNS & 2 & 1,9 \\
Lain-lain & 8 & 7,9 \\
Tidak bekerja & 1 & 0,9 \\
\hline
\end{tabular}

Tabel 5 Tingkat Pendidikan Ibu Hamil dengan infeksi HIV/AIDS di RSUP Dr. Hasan Sadikin Bandung periode 1 Januari 2014 - 31 Desember 2016

\begin{tabular}{|c|c|c|}
\hline $\begin{array}{c}\text { Tingkat } \\
\text { pendidikan }\end{array}$ & Jumlah & Persentase (\%) \\
\hline SD & 8 & 7,9 \\
\hline SMP & 19 & 18,6 \\
\hline SMA & 55 & 53,9 \\
\hline Diploma & 20 & 19,6 \\
\hline $\mathrm{S} 1$ & 0 & 0 \\
\hline
\end{tabular}

Berdasarkan tingkat pendidikan pada penelitian ini, tingkat pendidikan SMA merupakan yang terbanyak ditemukan yaitu 53,9\%. Tidak ada ibu hamil dengan tingkat pendidikan S1 yang terinfeksi HIV/ AIDS.

\section{Tabel 6 Status Pernikahan Ibu Hamil Dengan Infeksi HIV/AIDS di RSUP Dr. Hasan Sadikin Bandung Periode 1 Januari 2014-31 Desember 2016}

\begin{tabular}{lcc}
\hline $\begin{array}{c}\text { Status } \\
\text { Pernikahan }\end{array}$ & Jumlah & $\begin{array}{c}\text { Persentase } \\
(\mathbf{\%})\end{array}$ \\
\hline Menikah & 96 & 94,11 \\
Belum menikah & 2 & 1,96 \\
Janda & 4 & 3,92 \\
\hline
\end{tabular}

Pada tabel 6 memperlihatkan sebagian besar pasien pada penelitian ini sudah menikah yaitu $94,2 \%$.

\section{Pembahasan}

Dari tabel tersebut dapat dilihat bahwa 
terdapat 102 kasus ibu hamil dengan infeksi HIV yang berobat ke Klinik Teratai RS. Hasan Sadikin Bandung yang merupakan salah satu pusat pelayanan infeksi HIV di Jawa Barat periode 1 Januari 2014 sampai 31 Desember 2016. Dari 102 kasus itu dilihat karakteristik ibu hamil dengan infeksi HIV.

Ibu hamil dengan infeksi HIV terbanyak terdapat pada kelompok usia 30-39 tahun, yaitu sebanyak 62 kasus (60,78\%). 94,11\% ibu hamil dengan infeksi HIV sudah menikah. Bila dihubungkan dengan faktor resiko, penularan HIV terbanyak pada ibu hamil tersebut adalah melalui hubungan heteroseksual, yaitu 93 kasus (91,17\%).

Dengan demikian cara penularan HIV pada ibu hamil tersebut masih sama bila dibandingkan dengan tahun sebelumnya, yaitu melalui hubungan heteroseksual. Hal ini memungkinkan bahwa penularan HIV pada ibu-ibu hamil tersebut terjadi di dalam keluarga. Semua ibu hamil yang terinfeksi HIV tersebut, sudah memiliki anak dan sebagian besar dari kasus tersebut adalah multiparitas, yaitu 91 kasus ( 89,21\%). Untuk itu diperlukan konseling dan skrining pada semua anggota keluarga dari ibu hamil yang terinfeksi HIV tersebut agar pencegahan penularan HIV dalam keluarga dapat dilakukan dan pengobatan ARV dapat diberikan lebih awal. Hal yang sama juga dilaporkan oleh Suherlim R, dkk di Bali tahun 2015, melaporkan dari 42 pasien ibu hamil dengan infeksi HIV/AIDS ditemukan $54,8 \%$ penularan melalui heteroseksual. ${ }^{11}$

Bila dilihat dari faktor pekerjaan, infeksi HIV pada ibu hamil paling banyak terdapat pada ibu rumah tangga, 68 kasus $(66,66 \%)$. Hal ini semakin menguatkan kemungkinan bahwa penularan HIV pada ibu hamil tersebut terjadi di dalam keluarga. Konseling dan usaha-usaha preventif dan pengobatan dapat dilakukan pada keluargakeluarga yang terinfeksi HIV. Konseling ini kemungkinan akan efektif karena 55 kasus $(53,92 \%)$ dari ibu hamil dengan infeksi HIV tersebut memiliki tingkat pendidikan sekolah menengah atas dan $20(19,60 \%)$ diantara ibu hamil dengan infeksi HIV tersebut memiliki tingkat pendidikan diploma.

Perubahan karakteristik ini mungkin terjadi karena perubahan tingkat pendidikan, sehingga ibu hamil lebih mengetahui cara pencegahan terhadap penularan HIV. Penularan melalui narkoba suntik dan perilaku sex menyimpang sudah dihindari, namun ibu hamil tersebut lebih banyak tertular dari lingkungan kluarga sendiri baik antara suami dan istri maupun penularan dari ibu ke anak. Gambaran karakteristik ibu hamil dengan infeksi HIV ini dapat digunakan untuk menentukan sasaran dan metode yang tepat untuk melakukan pencegahan terhadap transmisi HIV pada ibu hamil.

Dengan karakteristik seperti sekarang, pencegahan penularan HIV lebih baik dilakukan ke dalam lingkungan keluarga. Penelitian ini merupakan studi retrospektif dengan menggunakan rekam medis sebagai sumber data sehingga pada penelitian ini tidak dilakukan uji etik. Simpulan, terdapat perubahan karakteristik ibu hamil dengan infeksi HIV di Rumah Sakit Hasan Sadikin Bandung.

\section{Saran}

Sebaiknya usaha pencegahan penularan infeksi HIV pada ibu hamil harus disesuaikan dengan karakteristik ibu hamil dengan infeksi HIV tersebut agar penurunan angka penularan infeksi HIV pada ibu hamil dapat ditingkatkan.

\section{Daftar Pustaka}

1. Workowski KA, Bolan GA. Sexually transmitted diseases treatment guidelines (2014). Reprod Endocrinol. 2014(24):516.

2. Weiler G. Global update on HIV treatment 2013: results, impact and opportunities. 
2013.

3. Data P, RI IKK. Situasi dan Analisis HIV AIDS. Diakses dari: www depkes go id/ resources/download/pusdatin/infodatin/ Infodatin\% 20A IDS pdf 27 Desember 2014]. 2014.

4. Kemenkes R. Pedoman Nasional Pencegahan Penularan HIV Dari Ibu Ke Anak (PPIA). Edisi Kedua Jakarta: Kementerian Kesehatan. 2012.

5. RSHS H. Klinik Teratai 'gak setengahsetengah' Tanggulangi HIV AIDS. Bandung: RSHS; 2013 [updated 2013; Diunduh 201726 Maret]; Tersedia dari: http://web.rshs.or.id/klinik-teratai-gaksetengah-setengah-tanggulangi-hiv-aids/

6. RSHS H. Lindungi Perempuan dan Anak dari HIV AIDS. Bandung: RSHS; 2013 [updated 2013; Diunduh 201726 April]; Tersedia dari: http://web.rshs.or.id/ lindungi-perempuan-anak-dari-hivaids/.

7. Drake AL, Wagner A, Richardson B, John-Stewart G. Incident HIV during pregnancy and postpartum and risk of mother-to-child HIV transmission: a systematic review and meta-analysis. PLoS Med. 2014;11(2):e1001608.
8. Townsend CL, Byrne L, CortinaBorja M, Thorne C, de Ruiter A, Lyall $\mathrm{H}$, et al. Earlier initiation of ART and further decline in mother-to-child HIV transmission rates, 2000-2011. AIDS. 2014;28(7):1049-57.

9. Macdonald EM, Ng R, Bayoumi AM, Raboud J, Brophy J, Masinde K-I, et al. Adverse neonatal outcomes among women living with HIV: a populationbased study. J Obstet Gynaecol Can. 2014;37(4):302-9.

10. Rimawi BH, Haddad L, Badell ML, Chakraborty R. Management of HIV Infection during Pregnancy in the United States: Updated Evidence-Based Recommendations and Future Potential Practices. Infect Dis Obstet Gynecol. 2016;2016.

11. Suherlim R, Subawa NAA. Karakteristik Penderita HIV pada Ibu Hamil di Klinik Prevention Mother to Child Transmission (PMTCT) Poli Kebidanan RSUP Sanglah Denpasar Periode Juli 2013 - Juni 2014. J Mahasiswa PSPD FK Universitas Tanjungpura. 2015;1(3):193-201. 